\title{
Corporeidade na oração à luz do Livro da Vida de Santa Teresa de Jesus
}

\author{
Orientador: Prof ${ }^{a}$ Lúcia Pedrosa de Pádua \\ Pesquisadora: Raísa Suena Soares Lopes \\ Projeto de Pesquisa: Espiritualidade, Teologia e Humanização \\ Fonte: $\mathrm{CNPq}$
}

A proposta da pesquisa foi investigar o tema da oração na sua relação com o corpo humano. A pesquisa buscou mostrar que é através do corpo que o ser humano é, está e se relaciona e, por isso, a oração e o corpo estão intimamente ligados. Sem a relação com a corporeidade, a oração se torna mero espiritualismo e alienação. A oração não deve estar desvinculada da vida nem a vida da oração, pois ambas se fecundam mutuamente.

A pesquisa teve como objetivo principal desenvolver o tema da corporeidade em sua relação com a oração em perspectiva positiva e integradora. Este objetivo temático mais geral se desdobrou nos seguintes objetivos específicos: reflexão sobre os fundamentos cristológicos e antropológicos da relação entre corpo e oração, e a pessoa de Jesus como exemplo, por excelência, de integração pessoal; desenvolvimento de aspectos da relação corporeidade e oração a partir do Livro da Vida de Santa Teresa de Jesus bem como a partir de autores especialistas em Santa Teresa.

Foi possível aprofundar no tema da oração numa perspectiva integral e integradora. Esta, sem dúvida, depende do desenvolvimento (de forma madura) das relações humanas, sempre buscando vinculá-las umas às outras. Quando o contrário acontece, ou seja, quando o ser humano nega sua necessidade de relacionar-se, este tornar-se-á lento no seu processo de humanização e consequentemente não terá uma oração fecundada pela vida nem uma vida fecundada pela oração. Buscando desenvolver bem suas relações e integrálas tanto quanto possível, o ser humano será capaz de desenvolver um sadio processo de humanização e uma sadia oração. 